DOI: $10.15290 /$ bsl.2017.10.04

\author{
Katarzyna Nadana-Sokołowska \\ Instytut Badań Literackich PAN \\ e-mail: katarzyna.nadana-sokolowska@ibl.waw.pl
}

\title{
Kieszonkowy atlas kobiet, Dzidzia, Cwaniary... - wybrane powieści Sylwii Chutnik w kontekście badań nad związkami reprezentacji wojny i płci kulturowej
}

Przez twórczość utożsamiającej się z feminizmem i Warszawą współczesnej pisarki Sylwii Chutnik (ur. 1979) wyraźnie przewija się motyw II wojny światowej. Jest on obecny w jej debiutanckiej powieści Kieszonkowy atlas kobiet (2008), w Dzidzi (2009) i Cwaniarach (2012). Chutnik chętnie wraca zwłaszcza do namysłu nad powstaniem warszawskim w kontekście specyficznego, a mało obecnego w przestrzeni publicznej doświadczenia kobiet. Przywołuje pamięć o kobietach biorących czynny udział w walce z bronią w ręku, ale także wyparte ze społecznej świadomości zbiorowe gwałty na warszawiankach po upadku powstania. Oba te wątki są do dzisiaj marginalizowane w oficjalnej pamięci, mimo zaznaczającej się od kilku lat mody na przywracanie opowieści o „morowych pannach” ${ }^{1}$. W prozie Chutnik stale

1 Na temat silnie stereotypowego opisu udziału kobiet $\mathrm{w}$ powstaniu $\mathrm{w}$ pracach $\mathrm{z}$ ostatnich lat pisała Weronika Grzebalska. Por. W. Grzebalska, Płeć powstania warszawskiego, Warszawa 2013. Grzebalska uważa, że choć wzmożone zainteresowanie historią udziału kobiet w powstaniu jest zjawiskiem $\mathrm{z}$ wielu względów pozytywnym, w dalszym ciągu reprodukuje konserwatywne stereotypy, sprowadzając rolę kobiet w powstaniu do pomocniczej - przede wszystkim sanitariuszki, która oprócz pomocy medycznej udziela wsparcia psychicznego (podziw dla odwagi powstańców, podtrzymywanie ich na duchu, pocieszanie w chorobie i umieraniu, flirt i romans). Jej książka jest przykładem herstorii pisanej z innej perspektywy: pokazuje, jak dyskurs wokół powstania, często nieświadomie powielany przez jej rozmówczynie (książka jest oparta na serii wywiadów z byłymi powstankami), powtarza i umacnia stereotypy o roli kobiet w wojnie, nie dopuszczając przede wszystkim do wypowiedzenia prawdy o kobiecym pragnieniu walki z bronią w ręku oraz o zakazach, jakie napotykają kobiety, próbujące realizować to pragnienie. Zakaz ten znajduje się także u źródeł późniejszego wyciszania relacji o ich udziale w walkach i dyskusji na ten temat. 
powraca także motyw współczesnych kobiet-wojowniczek: anarchistek, terrorystek itp. (postaci nawiązujące wyraźnie do bohaterek kultury popularnej, na przykład wywodzącej się z gier komputerowych Lary Croft), decydujących się na "miejską partyzantkę" w odpowiedzi na społeczną bezsilność wobec tych, którzy ignorują problemy spauperyzowanej ludności miejskiej.

Związki, w jakie wchodzą u Chutnik kategorie wojny i kobiecości, warto przedstawić na tle toczącej się na Zachodzie od schyłku XX wieku debaty na temat wojennego doświadczenia kobiet i kobiecych ról podczas konfliktów zbrojnych. Poniżej przedstawiam ogólne wnioski z najważniejszych książek poświęconych temu tematowi ${ }^{2}$.

To między innymi liczne kobiece dokumenty z czasów I i II wojny światowej i nie tylko (dzienniki, listy, autobiografie, wspomnienia) dostarczyły badaczom materiału pozwalającego zakwestionować tradycyjne przekonania o męskich i kobiecych rolach w czasie wojny, w tym przede wszystkim przeświadczenie, że walka i bohaterstwo to wyłącznie domena mężczyzn. Jest ono oparte na głębszym założeniu, że w czasie wojny mężczyzna jest aktywny, a kobieta pasywna. Wojna - jak wykazują - była tradycyjnie uznawana wręcz za warunek utwierdzenia czy potwierdzenia męskości mężczyzny i w tym sensie pożądana jako element budowania jego tożsamości i biografii. Mężczyzna - wojownik i obrońca, aktywny podmiot wojny, przeciwstawiany jest kobiecie, która biernie doświadcza skutków walki. Mężczyzna w czasie wojny ma możliwość stania się bohaterem, wpisania się imieniem i nazwiskiem na trwałe w pamięć zbiorową, kobieta zaś to przede wszystkim potencjalna

2 Ważne pozycje w tej debacie to na przykład: J. Bourke, Dismembering the Male. Men's Bodies, Britain and the Great War, Chicago 1996; J. Burke, An intimate History of Killing. Face-to-Face Killing in twentieth-century Warfare, New York 1999; Crossing the Border. Voices of Refugee and Exiled Women, ed. J. Langer, Nottinhgam 2002; B.J. Davis, Home Fires Burning. Food, Politics and Everyday Life in World War I Berlin, Chapel Hill 2000; B. Ehrenreich, Rytuały krwi. Namiętność do wojny. Geneza i historia, Warszawa 2001; Gender and War in Twentieth-Century Eastern Europe, ed. N.M. Wingfield, M. Bucur, Bloomington 2006; J.S. Goldstain, War and Gender. How Gender Shapes the War System and Vice Versa, Cambridge 2001; S.R. Grayzel, Woman's Identities at War. Gender, Motherhood, and Politics in Britain and France during the First World War, Chapel Hill 1999; M. Healy, Vienna and the Fall of Habsburg Empire. Total War and Everyday Life in World War I, New York 2004; Home/Front. The Military, War and Gender in Twentieth-Century Germany, ed. K. Hagemann, S. Schüler-Springorum, Berg 2000; N. Tec, Resilience and Courage. Men. Women and the Holocaust, Yale University Press 2003; A. Watson, Enduring the Great War. Combat, Morale and Collapse in the German and British Armies, 1914-1918, New York 2008; A. Watson, Ring of Steel. Germany and Austria-Hungary in World War I, New York 2014; J.S.K. Watson, Fighting Different Wars. Experience, Memory, and the First World War in Britain, New York 2004; Women and Men at War. A Gender perspective on World War II and its Aftermath in Central and Eastern Europe, ed. M. Röger, R. Leiserowitz, Osnabrück 2012; Women and the Holocaust, eds. D. Ofer, I. Weitzmann, Yale University Press 1988. 
ofiara wojny, czyli ktoś, kogo trzeba bronić. Różnicy między męskością a kobiecością odpowiada tu cała sieć binarnych, zhierarchizowanych różnic pomiędzy siłą i słabością, aktywnością i pasywnością, męstwem i strachem itp.

Zestaw ról kobiecych $\mathrm{w}$ czasie wojny opisany w Iliadzie Homera praktycznie nie uległ do dziś zmianie w wyobraźni zbiorowej większości społeczeństw: kobieta albo jest przyczyną wojny (Helena), albo jej ofiarą (Hekuba czy branki wodzów achajskich). Postać Hekuby, żony króla Priama, to budząca litość i trwogę figura doświadczonej nieszczęściami matki narodu: musi patrzeć na klęskę królestwa, być świadkiem śmierci męża i synów oraz gwałtów na córkach ${ }^{3}$, zaś często bezimienne branki, które chwilę wcześniej były bezsilnymi świadkami śmierci swych najbliższych, to figury skrajnie uprzedmiotowionych seksualnych niewolnic - sprowadzonych do roli wojennego łupu dostarczającego wojownikom należnej przyjemności w czasie wolnym, przedstawianych mimo to jako te, które potrafią nawet pokochać swoich oprawców.

W tradycyjnej historiografii działania wojowników, czyli wojsk i ich wodzów, są dużo ważniejsze niż cywilne doświadczenie wojny, postrzegane jako związane ze sferą niehistorycznej codzienności, nieistotnej i niezasługującej na upamiętnienie. Ponieważ stereotypy związane $\mathrm{z}$ postrzeganiem wojny są bardzo silne, a kod męsko-heroiczny, łączący wojnę/walkę z męskością wciąż uruchomiany do jej opisu, nasze społeczeństwa mają kłopot $z$ dostrzeżeniem i docenieniem specyfiki kobiecej aktywności, a nawet bohaterstwa w czasie wojny (zarówno tej na polu walki, na którym wbrew stereotypowi kobiety zawsze były obecne, jak tej na zapleczu frontu), i z opisem i upamiętnieniem specyficznych, związanych z cielesnością kobiet cierpień i zbrodni, na które wojna je naraża.

Tradycyjna rola przypisana kobiecie w społeczeństwie jest związana ze sferą życia prywatnego, rodzinnego, a w szczególności z macierzyństwem, opieką nad domownikami i prowadzeniem domu. Dlatego kobieca dzielność w czasie wojny najczęściej przyjmuje formę wzmożonych zabiegów wokół przetrwania rodziny i bliskich, często $\mathrm{w}$ drastycznych, narażających je na przemoc i śmierć warunkach. W tym sensie doświadczenie kobiet jako cywili także zasługuje na wpisanie we wzorzec walki, a codzienne zmagania o przetrwanie bliskich, o ich bezpieczeństwo i zaspokojenie podstawowych potrzeb oraz praca organizacyjna na rzecz lokalnej społeczności czy walczących na froncie żołnierzy, mogą w warunkach wojennych nabrać cech heroicznych.

\footnotetext{
3 O figurach tych pisała na przykład Inga Iwasiów w artykule Centralna płeć cywila, w: Wojna - doświadczenie i zapis: nowe źródła, problemy, metody badawcze, red. S. Buryła i P. Rodak, Kraków 2006.
} 
Warto zauważyć, że kobiety pozbawione pomocy mężczyzn walczących na froncie, opiekując się dziećmi i innymi słabszymi członkami rodziny, decydują się na aktywności wychodzące poza typowe rozumienie roli kobiecej, podejmując - często bardzo ciężkie - prace zarobkowe, lub przejmując na siebie obowiązki rozumiane podczas pokoju jako powinności głowy rodziny. Często w ekstremalnych sytuacjach biorą na siebie odpowiedzialność za bezpieczeństwo bliskich, zapewniają im aprowizację $\mathrm{w}$ warunkach bezpośredniego zagrożenia śmiercią itp. Ich zachowanie podczas wojny stanowi mocny dowód na stereotypowość określenia "słaba płeć” i przypisania tego, co żeńskie do sfery prywatnej. To pamięć tych doświadczeń w czasie I wojny światowej upewniła wiele kobiet $\mathrm{w}$ Europie o potrzebie walki o swoje prawa w obszarze publicznym, czyli - wtedy - prawa wyborcze, a pamięć o ich roli $\mathrm{w}$ tej wojnie skłoniła wielu polityków do zajęcia stanowiska, że prawa te im się rzeczywiście należą.

Kobieca dzielność w czasie wojny dotyczy jednak nie tylko aktywności na zapleczu frontu, ale także zaangażowania $w$ walkę zbrojną. Tradycyjną i społecznie akceptowaną rolą kobiety, związaną z jej uczestnictwem $\mathrm{w}$ walce, jest rola pomocnicza, zwłaszcza otoczona rozmaitymi seksualnymi konotacjami rola sanitariuszki, ale także organizatorki, łączniczki itp. Kobiece wspomnienia i autobiografie dostarczają wielu opisów pełnienia tego rodzaju funkcji, pozwalających nie tylko ocenić skalę kobiecego uczestnictwa w tych wymiarach wojny, ale także dostrzec deprecjonujący sposób postrzegania tych zajęć przez mężczyzn, odmawiających uznania ich rzeczywistej, ogromnej wagi dla powodzenia działań na froncie. Co więcej, same kobiety często uwewnętrzniają ten deprecjonujący obraz swojej aktywności, traktując ją jako oczywistą i niezasługującą na szczególne uznanie, pomimo niewyobrażalnej intensywności ich pracy oraz bezpośredniego narażenia życia w pobliżu i na polu walki.

Największe kontrowersje budzi jednak bezpośrednia walka kobiet na pierwszych liniach frontu. Kobieta-wojowniczka to z jednej strony rola przypisana na czas wojny jednostkom wyjątkowym, a z drugiej obrosła wieloma uprzedzeniami i marginalizowana w historiografii. Kobiece dokumenty wojenne znów mogą posłużyć zarówno jako źródło wiedzy o rozmiarach i charakterze zaangażowania kobiet $\mathrm{w}$ walkę $\mathrm{z}$ bronią $\mathrm{w}$ ręku, jak i interesujące świadectwo sposobu traktowania kobiet-żołnierek przez otoczenie w czasie wojny i po niej. Przykładem takiego dokumentu jest dziennik Nadieżdy Durowej Zapiski kavalerist-devitsy, prowadzony przez nią w czasie wojen napoleońskich w latach 1807-1816 (opublikowany w Rosji w 1936 roku) ${ }^{4}$. Du-

\footnotetext{
4 Polskie tłumaczenie brzmiałoby Zapiski kawalerzysty-dziewicy; polskiego wydania brak.
} 
rowa - jak większość kobiet walczących z bronią w ręku - służyła w armii w męskim przebraniu. Kiedy podstęp się wydał, jej odwaga wzbudziła powszechne uznanie, a car nagrodził ją wojskowym awansem.

Figurę kobiety-wojowniczki znajdziemy już w antyku. To na przykład biblijna Judyta, która od początku budzi sprzeczne reakcje emocjonalne: $\mathrm{z}$ jednej strony jest postrzegana jako bohaterka, $\mathrm{z}$ drugiej - femme fatale. Walczy, posługując się swoją seksualnością jako wyrafinowanym rodzajem broni, wobec którego mężczyzna okazuje się bezsilny. Judyta budzi więc tyleż podziw i wdzięczność, co skrytą odrazę i strach. Inne warianty kobiet-wojowniczek to znane z greckiej mitologii Amazonki czy Joanna d'Arc. Również jej historia jest dwuznaczna, budząc zarówno podziw dla jej „męstwa" i patriotyzmu, jak i lęk przed przekroczeniem binarnych podziałów płciowych - przed kobietą, która wygląda i zachowuje się jak mężczyzna. W polskiej wyobraźni zbiorowej najważniejszymi figurami kobiet-wojowniczek są Emilia Plater i mickiewiczowska Grażyna, a także mityczna królewna Wanda, jednocześnie jednak pamięć zbiorowa nie podtrzymuje kultu takich postaci, jak na przykład Joanna Żubrowa, biorąca udział w powstaniu styczniowym, czy kobiety walczące w Legionach Piłsudskiego, a przecież były ich setki.

O ile aktywność kobiet w walce zbrojnej budzi podziw jako wyraz ich patriotyzmu, o tyle wiążą się z nią równocześnie charakterystyczne ograniczenia. Kobieta walcząca traktowana jest jako wyjątek i tolerowana tylko w sytuacji wyjątkowej. Oczekuje się od niej z jednej strony pewnej powściągliwości w okazywaniu chęci walki, zwłaszcza zabijania (o ile możliwe, powinna w bezpośrednim starciu ustąpić miejsca mężczyznom, pozwalać się im chronić - stąd kobiety dopuszcza się do formacji wojskowych w szczególnych rolach, na przykład łączniczek, wywiadu itp.). Z drugiej strony oczekuje się od niej traktowania roli żołnierza jako wyjątkowego epizodu w jej życiu, wyjętego niejako poza nawias biografii, to znaczy niełączącego się trwale z jej poczuciem tożsamości.

Kobieta w czasie pokoju powinna wrócić do pełnienia swej zwykłej roli, a jeśli się temu sprzeciwia, naraża się na społeczny ostracyzm. Mimo żywego udziału kobiet w I i II wojnie światowej, w dyskursie publicznym po ich zakończeniu silnie zaznaczyło się konserwatywne wezwanie zalecające kobietom powrót do ich tradycyjnych ról, płynące $\mathrm{z}$ lęku przed ich pełną emancypacją. Taki sens mają praktyki uniewidoczniania wkładu kobiet w działania zbrojne w zinstytucjonalizowanych formach kultywowania pamięci o wojnie, a także marginalizowania i wytłumiania kobiecych aspiracji do uczestnictwa $\mathrm{w}$ formacjach wojskowych $\mathrm{w}$ czasie pokoju. Ciekawym przykładem jest tu - opisany przez Alicję Kusiak-Brownstein - stosunek władz II Rzeczpospoli- 
tej do kobiet, które brały czynny udział w I wojnie światowej, a po niej chciały nadal czuć się żołnierzami i domagały się utrzymania kobiecych oddziałów w wojsku. Władze nie spełniły ich postulatów, dlatego założone przez bohaterkę walk, Wandę Geertz, paramilitarne POdOK (Przysposobienie Kobiet do Obronności Kraju) działały aż do 1935 roku wyłącznie w formie organizacji kobiecej. Dopiero zagrożenie kolejną wojną sprawiło, że z efemerydy jednostka ta stała się paramilitarną organizacją masową, popieraną przez władze i wojsko ${ }^{5}$.

Badacze o orientacji gender od dawna za nieprzypadkowy uważają zresztą fakt, że mityczne postacie kobiet-wojowniczek najczęściej ponoszą śmierć jeszcze w czasie wojny. Łatwiej czcić umarłą kobietę-bohaterkę (Emilia Plater), niż za życia otaczać kultem takie postaci, jak wspomniane już Żubrowa czy Geertz, ponieważ wojna podważa binarny podział ról płciowych, obnażając jego arbitralność zakorzenioną w kulturze, a nie w naturze, rzekomo czyniącej kobiety niezdolnymi do samoobrony, walki i bohaterstwa. Dlatego przywrócenie ładu społecznego po wojnie wydaje się wymagać wymazania z pamięci faktów o aktywności kobiet wykraczających poza swoją tradycyjną rolę, tak, aby pamięć ta nie mogła tego porządku podważać.

Na koniec rozważań o męskich i kobiecych rolach podczas wojny trzeba powiedzieć, że heroiczny kod rozumienia wojny eksponuje jako wartościową - w sensie poświęcenia za ojczyznę itp. - śmierć żołnierza na polu walki czy z odniesionych ran, a marginalizuje cierpienia, które stają się udziałem kobiet (i oczywiście innych cywilów) - takie na przykład, jak bezdomność, wygnanie, doświadczenie śmierci bliskich, w tym dzieci ${ }^{6}$. Choć cielesność kobiet podczas wojny czyni je także potencjalnymi ofiarami specyficznych przestępstw, związanych z ich seksualnością: gwałtów wojennych, wymuszonej prostytucji w obozach itp., jest to obszar kulturowego tabu, który sprawia, że zarówno opis tych doświadczeń przez same kobiety, jak ich upamiętnianie jest bardzo trudne. Jak wiemy, gwałty wojenne dopiero niedawno (rezolucja Rady Bezpieczeństwa ONZ z czerwca 2008 roku) uznano zarazem za taktykę wojenną i zbrodnię przeciwko ludzkości.

\footnotetext{
5 Por. A. Kusiak-Brownstein, Płeć kulturowa, "doświadczenie” i wojna - kilka metodologicznych uwag o wykorzystaniu relacji wspomnieniowych, w: Kobieta i rewolucja obyczajowa. Społeczno-kulturowe aspekty seksualności. Wiek XIX i XX, red. A. Żarnowska, A. Szwarc, Warszawa 2005.

6 Pierwszą próbę opisu doświadczeń polskich cywilów w czasie I wojny światowej, ze szczególnym uwzględnieniem kobiet oraz dzienników i wspomnień jako traktowanego dotąd z nieufnością źródła historycznego, stworzyła w Polsce dopiero niedawno Katarzyna Sierakowska. Por. K. Sierakowska, Śmierć, wygnanie, głód w dokumentach osobistych. Ziemie polskie w latach Wielkiej Wojny 1914-1918, Warszawa 2015. Sierakowska od wielu lat bada między innymi udział Polek w I i II wojnie światowej oraz jego kulturowe postrzeganie.
} 
Widząc niewystarczalność istniejących materiałów źródłowych, które silnie uwikłane $\mathrm{w}$ konwencje i tabu - zdradzają prawdę o wojennym doświadczeniu kobiet często tylko pośrednio, współcześni badacze związków kobiecości z wojną odwołują się chętnie do metody badań określanej jako oral history. Metoda wywiadu biograficznego, zakładającego empatyczny kontakt historyka/dziennikarza $\mathrm{z}$ uczestnikami zdarzeń, pozwala na znaczące dopełnienie naszej wiedzy. W tym miejscu jako przykład warto przywołać frapującą książkę Swietłany Aleksijewicz, białoruskiej dziennikarki i dziś już Noblistki, która przez kilkadziesiąt lat przeprowadzała wywiady z kobietami z byłego ZSRR, uczestniczącymi w II wojnie światowej (było ich około miliona).

Książka Wojna nie ma w sobie nic $z$ kobiety ${ }^{7}$ pozwala na prześledzenie w relacjach kobiet wszystkich wątków, o których powyżej wspomniałam, mimo iż powstała niezależnie i wcześniej od wspomnianego nurtu badań zachodnich. Warto przy tym zauważyć - i będzie to uwaga ważna także w kontekście prozy Chutnik - że spontaniczna, wyrwana w sprzyjających warunkach $\mathrm{z}$ obowiązujących ram opowiadania o wojnie, za to poddana emocjom i skojarzeniom rozmowa jako forma wypowiedzi, wydaje się stwarzać wyjątkowe możliwości wyrazu wojennego doświadczenia. Sytuuje się ono wtedy poza kodem heroicznym, ale i poza dyskursem naturalistycznym, typowym dla pacyfistycznej prozy po I wojnie światowej. Skupia się za to na próbach wyrazu wojennego doświadczenia jako odczucia niecodziennej codzienności. Miesza w niedopuszczalny w utrwalonych formach wyrazu sposób to, co wzniosłe, z tym, co trywialne, bohaterstwo z rutyną czy cierpienie $\mathrm{z}$ obojętnością. Jest także $\mathrm{w}$ stanie pomieścić całą gamę uczuć i refleksji zwykle nieobecnych $w$ relacjach o wojnie, na przykład poświęconych zniszczeniu przyrody czy cierpieniu zwierząt (wątek ten pojawia się bardzo często $\mathrm{w}$ refleksjach snutych przez rozmówczynie dziennikarki).

Nieprzypadkowo Aleksijewicz określa cel swojej pracy jako odtwarzanie historii ludzkiej duszy. Wojna jest dla niej ważna jako część ludzkiego doświadczenia. Najbardziej interesują ją nie przebieg działań wojennych, na których skupia się historiografia, ale emocje i refleksje rozmówczyń. Rozmawia $\mathrm{z}$ kobietami po pierwsze dlatego, że przed nią nikt $\mathrm{w}$ ZSRR tego nie robił, przynajmniej nie $\mathrm{w}$ ten sposób, a po drugie dlatego, że zauważyła, iż

7 Por. S. Aleksijewicz, Wojna nie ma w sobie nic z kobiety, przeł. J. Czech, Wołowiec 2015. Co ciekawe, książka ta w pierwotnej wersji powstała jeszcze w latach 70 . XX wieku, ale musiała czekać na publikację do pieriestrojki Gorbaczowa. Polski przekład oparty jest na rosyjskim wydaniu z 2007 roku, które znacznie różni się od pierwotnej, ocenzurowanej wersji książki. 
mężczyznom trudniej wyrażać emocje i opowiadać o wojennej codzienności, ponieważ silniej identyfikują się z tradycyjną narracją o wojnie jako historii walk. W literaturze polskiej po możliwości wyrazu ukryte w mowie potocznej, w zwykłej "gadaninie o powstaniu", sięgnęli w latach 70. XX w. Miron Białoszewski w Pamiętniku z Powstania Warszawskiego oraz Anna Świrszczyńska w Budowałam barykadę. Te obie książki wyraźnie patronują także twórczości Chutnik.

Przedstawione powyżej wnioski z badań nad związkami wojny i kulturowego konstruowania płci mają swój wyraźny odpowiednik w jej prozie ${ }^{8}$. Chutnik najchętniej opisuje Warszawę: życie codzienne lub niezwykłe losy jej mieszkańców, zwłaszcza kobiet, warszawski folklor miejski, reprezentantki rozmaitych współczesnych subkultur. Ogromne znaczenie dla jej rozumienia Warszawy ma niezinstytucjonalizowana, mówiona pamięć o powstaniu warszawskim, która okazuje się pamięcią kobiet.

Powstańczynią jest jedna z bohaterek Kieszonkowego atlasu kobiet (2008) Maria Wachelberska. To rodowita warszawianka, której ojciec został zabity w getcie, a matka stała się ofiarą gwałtu i zabójstwa na ochockim Zieleniaku dzisiejszym bazarze przy Banacha, na który po powstaniu spędzono ludność cywilną i gdzie masowo gwałcono i mordowano kobiety. Maria, czując się zarówno Żydówką, jak i Polką, brała udział i w powstaniu w getcie, i w powstaniu warszawskim, a po jego upadku trafiła na wspomniany Zieleniak i była świadkiem śmierci matki, która zginęła, chcąc ją samą uchronić przed gwałtem. Maria spędziła dzieciństwo na ulicy Opaczewskiej i tu wróciła po wojnie. Kiedy ją poznajemy, ma około 80 lat i prowadzi życie osoby z marginesu - nikomu niepotrzebnej, ubogiej staruszki, która w końcu decyduje się opuścić mieszkanie i przenieść do piwnic kamienicy, aby tam oczekiwać na śmierć, bez końca rozpamiętując powstańcze dzieje, będące także dziejami ludzi kryjących się i ginących $w$ tych piwnicach.

Życie Walchelberskiej naznaczone jest wojenną traumą, związaną zarówno z doświadczeniem śmierci rodziców, zwłaszcza matki, jak z doświadczeniem udziału w obu powstaniach. Trauma ta izoluje ją od otoczenia i skazuje na egzystencję na marginesie społeczeństwa - bohaterka nie jest w stanie założyć rodziny ani do nikogo zbliżyć się emocjonalnie. Jej życie wyczerpuje się w rutynie pracy urzędniczki. Nie odnajduje się nawet we wspólnocie kombatantów, przede wszystkim dlatego, że nie ma potrzeby wpisania sa-

\footnotetext{
8 O przedstawieniu wojny u Chutnik w kontekście tak zwanej postpamięci, czyli pamięci o wojnie właściwej pokoleniom, które jej bezpośrednio nie doświadczyły, pisała już Aleksandra Ubertowska. Por. A. Ubertowska, Archeologie pamięci. Wspótczesne kobiece narracje o wojnie, w: Wojna i postpamięć, red. Z. Majchrowski, W. Owczarski, Gdańsk 2011.
} 
mej siebie w narrację bohaterską. Podobnie jak wiele innych kobiet-uczestniczek powstania dobrowolnie godzi się na marginalizację, nie czując się bohaterką i nie oczekując traktowania siebie w ten sposób. W zamian rozpamiętuje $\mathrm{w}$ samotności swoje doświadczenia graniczne związane $\mathrm{z}$ wojną (takie jak na przykład przeprowadzanie powstańców przez kanały i towarzyszenie ich śmierci).

Wachelberska dożywa swoich osiemdziesięciu kilku lat nie tylko doświadczając marginalizacji i degradacji jako stara kobieta, ale także strachu: w jej świadomości wojna trwa w pewnym sensie nadal, bo czuje się zagrożona przez widoczne dla niej, jako potencjalnej ofiary, oznaki antysemityzmu (w postaci rozmaitych bazarowych gadek czy miejskich grafitti). Zrepresjonowana jest nie tylko jej pamięć jako kobiety-powstanki, ale zwłaszcza jako powstanki z getta - Wachelberska boi się ujawnić swoje żydowskie pochodzenie, nie wiedząc, że w rzeczywistości wszyscy jej sąsiedzi są go świadomi. Do końca życia rozpamiętuje zdarzenia z Zieleniaka - brutalne gwałty na warszawiankach, a zwłaszcza śmierć matki. To także obszar społecznej niepamięci - Zieleniak, jak zauważa bohaterka, nie był po wojnie upamiętniony jako miejsce związane z narodową martyrologią. Mechanizmy wyparcia i tabuizacji sprawiają, że kobiece doświadczenie wojny nie ma swojego języka i swojej pamięci, bo dotycząc kobiecej seksualności, wiąże się ze wstydem i piętnem.

Choć w bliskim sąsiedztwie Wachelberskiej mieszkają dwie dziewczyny (anarchizujące dwudziesto- i dwunastolatka), którym mogłaby się stać bardzo bliska, gdyby ją znały, kobieta umiera w zapomnieniu i lekceważeniu, także z ich strony. Niemożność komunikacji, przekazania doświadczenia kobiecej walki z pokolenia na pokolenie, nie jest tu przypadkiem, lecz okazuje się wpisana w strukturę społeczeństwa, które rządzi się mechanizmami izolującymi kobiety od siebie wzajemnie, zapobiegającymi powstaniu więzi szacunku opartej na podziwie dla życiowych dokonań.

Chutnik tworzy postać Wachelberskiej z elementów wiedzy dostępnej jej dzięki studiom gender $\mathrm{w}$ obrębie polskiej historii. Nie ma tu niedomówień, jest wyraźna teza (marginalizacja kobiet w pamięci historycznej i polski antysemityzm), jej ilustracja (los Wachelberskiej) i feministyczne wezwanie do interwencji (odpominanie zapomnianego, przyswojenie przez kobiety swojej historii i utożsamienie z kobiecymi bohaterkami). Te dwa pokolenia kobiet - powstanek i współczesnych anarcho-feministek - zostaną ukazane także w Cwaniarach (2012). Chutnik opisuje w powieści współczesne warszawskie środowisko chuliganek, tworząc figurę wojowniczki-anarchistki-terrorystki. Inaczej jednak niż w Atlasie kobiet, gdzie powstańczyni i młode anarchistki żyją w nieprzenikalnych dla siebie światach, poka- 
zuje, że te współczesne warszawskie bojowniczki wywodzą swą genealogię właśnie od powstańczyni.

W figurze współczesnej wojowniczki Chutnik przekracza binarne podziały płciowe: Halina Żyleta przynależy całkowicie do świata kobiet - jest opłakującą narzeczonego wdową w ostatnich tygodniach ciąży, spędzającą chętnie czas na typowo kobiecych zajęciach, jak gotowanie, wizyty u kosmetyczki i spotkania z przyjaciółkami w kawiarni. Jednocześnie czyni swą misją wymierzanie sprawiedliwości panoszącym się w miejskiej przestrzeni, pełnym pogardy dla kobiet dresiarzom. Halina wchodzi w rolę wojowniczki, ponieważ bulwersują ją zachowania, do których inni się przyzwyczajają, wypierają ze świadomości. W pewnym sensie mści się wciąż za swoje pierwsze traumatyczne doświadczenie, którym była próba zgwałcenia przez kolegę $\mathrm{z}$ osiedla.

Dla Haliny wzorem osobowym jest jej babcia Genia, która uczestniczyła w powstaniu warszawskim jako łączniczka i kanalarka. Bohaterce wydaje się, że to ją właśnie naśladuje jako samozwańcza bojowniczka o ład moralny w mieście. W końcu obie kobiety łączą się we wspólnej walce. Banda Haliny podejmuje misję wymierzenia sprawiedliwości mafioso odpowiedzialnemu za śmierć kilku osób buntujących się przeciwko eksmisjom i wyburzaniu starych warszawskich kamienic, a babcia Genia uczestniczy w tym przedsięwzięciu, przeprowadzając bandę do celu kanałami.

Dla Haliny i babci Geni wojna w pewnym sensie się nie kończy: dzisiejszym okupantem Warszawy okazują się nieuczciwi kapitaliści wykupujący grunty, niszczący starą zabudowę miasta i nieliczący się ze spauperyzowanymi mieszkańcami przedwojennych kamienic. Okupanci ci narażają się na słuszny gniew i zemstę warszawskiego ludu. Niestety, tak jak w czasie powstania, walka jest nierówna i Halina Żyleta decyduje się na samobójstwo, osierocając dopiero co urodzone dziecko, aby po udanym zamachu uniknąć długoletniego więzienia.

W Cwaniarach Chutnik tworzy więc wersję udanego transferu międzypokoleniowego między babciami-powstankami i ich wnuczkami-anarcho-feministkami, nadając zarazem reprezentantkom obu tych generacji cechy heroiczne i mityczne.

W pewnym sensie najciekawszą, bo najbardziej formalnie skomplikowaną z jej powieści nawiązujących do czasu wojny jest opublikowana w 2009 roku Dzidzia. Tytułowa Dzidzia to dziewczynka-potwór: kalekie dziecko, skazane na czystą wegetację. Dzidzia urodziła się bez kończyn, z wieloma nieuleczalnymi dolegliwościami somatycznymi, niedowładem mięśni krtani i upośledzeniem umysłowym. Dzidzia nie może więc komunikować się z otoczeniem, choć zarazem okazuje się swoistym medium: jej ciało odbiera 
wciąż sygnały związane ze zbiorową pamięcią warszawiaków, a właściwie warszawianek, porównane przez narratora do nieustającej audycji radiowej. Pamięć ta mimo upływu lat koncentruje się wokól doświadczenia wojny i powstania.

Groteskowa postać Dzidzi okazuje się od urodzenia całkowicie zamknięta w wojennej historii - zgodnie $\mathrm{z}$ cichym przeświadczeniem mieszkańców miasteczka jej kalectwo jest karą za grzech babki, która powodowana chciwością wydała Niemcom dwie kobiety ukrywające się u niej po powstaniu warszawskim. Napiętnowana, zostaje zarazem wyróżniona przez los, mając dostęp do podskórnego nurtu pamięci. Przekazy, które do niej docierają, to jakby snute w nieskończoność opowieści warszawskich „bab”, opisujących cierpienia miasta podczas powstania: śmierć swoich dzieci, gehennę, makabrę, graniczący z absurdem codzienny heroizm $\mathrm{w}$ próbach zaradzenia śmierci i nieszczęściu.

Tym samym Didzia ma dostęp do kobiecej narracji, wypartej z uwznioślonej i zinstytucjonalizowanej pamięci o powstaniu: jest to opowieść o przypadkach, które co chwila decydowały o śmierci i życiu, o trosce o podstawy bytu swoich bliskich, a także zmysłowa pamięć o powstaniu widzianym od strony braku dostępu do wody, zapachu rozkładających się trupów czy umazanych kałem powstańców wychodzących z kanałów.

Groza powstania woła ustami kobiet o zaprzestanie walki - jest to ich główny przekaz do dowódców powstania, którzy, w ich przekonaniu, nie szanują ludzkiego życia. Kobiecy punkt widzenia na powstanie okazuje się tu zasadniczo inny niż męski, upatrujący w nim okazji do wykazania się bohaterstwem i ofiarnej śmierci za ojczyznę, nie ma jednak żadnej kulturowej mocy sprawczej. Takie babskie opowieści, uważane w kulturze za mniej wartościowe, skonfliktowane $\mathrm{z}$ uprzywilejowaną narracją bohaterską, można w powieści potraktować jako wspomnianą oral history - historię mówioną, do której dostęp ma jednak tylko Dzidzia - skazaną zatem na zapomnienie. Chutnik tytułuje te audycje z wnętrza brzucha dziewczynki pogardliwie, przypominając o lekceważeniu, z jakim spotykają się opowieści snute przez staruszki: "Stara baba gada, stara baba męczy" .

Mottem do książki czyni historię przytoczoną przez Claude Lanzmana o dziecku-monstrum, które urodziło się w 1942 roku w Warszawie państwu Borowym: "to historia wydała przez nich to monstrum, to był protest przeciwko temu, co się wokół działo, przeciwko dochodzącemu zewsząd smrodowi trupów [...]". Te słowa każą się doszukiwać swoistej historiozofii także

9 S. Chutnik, Dzidzia, Warszawa 2009, s. 44. 
w narodzinach Dzidzi. I nie jest to historiozofia oparta na prostym poczuciu kary za grzechy przodków, ale raczej dostrzegająca wypartą z oficjalnego dyskursu monstrualność polskiej historii i polskiej teraźniejszości jako jej wyniku. Współcześnie ta monstrualność objawia się między innymi w losach matki Dzidzi, która poświęca się opiece nad córką, żyjąc w nędzy i pogardzie - nikt nie jest zainteresowany tym, aby ją wesprzeć $w$ jej codziennym kobiecym trudzie.

Chutnik formułuje swoje tezy jak zwykle wprost: „Historia przemiela się $\mathrm{w}$ niepełnosprawnej dziewczynce. Jaka historia, takie medium. Miasto zbudowane $\mathrm{z}$ trupów, na trupach. Dzieciaki pognane z motykami na słońce, przecież ciała swoje gubiły po drodze"10. Groteskowa postać Dzidzi, która w zakończeniu powieści wbrew niemożliwości toczy się przez kraj, nie mogąc nikomu zakomunikować swojej wiedzy, stanowi figurę tego, co wyparte z polskiej pamięci o wojnie: jest zarazem niesłyszalna i wszechobecna.

\section{Bibliografia}

Aleksijewicz Swietłana, Wojna nie ma w sobie nic z kobiety, przeł. J. Czech, Wołowiec: Wydawnictwo Czarne, 2015.

Bourke Joanna, Dismembering the Male. Men's Bodies, Britain and the Great War, Chicago: University of Chicago Press, 1996.

Burke Joanna, An intimate History of Killing. Face-to-Face Killing in twentieth-century Warfare, New York: Basic Books, 1999.

Chutnik Sylwia, Dzidzia, Warszawa: Świat Książki, 2009.

Chutnik Sylwia, Kieszonkowy atlas kobiet, Kraków: Korporacja Ha!art, 2008.

Chutnik Sylwia, Cwaniary, Warszawa: Świat Książki, 2013.

Crossing the Border. Voices of Refugee and Exiled Women, ed. J. Langer, Nottinhgam: Five Leaves Publications, 2002.

Davis Belinda J., Home Fires Burning. Food, Politics and Everyday Life in World War I Berlin, Chapel Hill and London: University of North Carolina Press, 2000.

Ehrenreich Barbara, Rytuały krwi. Namiętność do wojny. Geneza i historia, przeł. P. Kołyszko, Warszawa: Jacek Santorski \& Ska, 2001.

Gender and War in Twentieth-Century Eastern Europe, eds. N.M. Wingfield, M. Bucur, Bloomington: Indiana University Press, 2006.

Goldstain Joshua S., War and Gender. How Gender Shapes the War System and Vice Versa, Cambridge: Cambridge University Press, 2001.

10 Tamże, s. 46. 
Grayzel Susan R., Woman's Identities at War. Gender, Motherhood, and Politics in Britain and France during the First World War, Chapel Hill: University of North Carolina Press, 1999.

Grzebalska Weronika, Płeć powstania warszawskiego, Warszawa: Wydawnictwo IBL PAN, 2013.

Healy Maureen, Vienna and the Fall of Habsburg Empire. Total War and Everyday Life in World War I, Cambridge: Cambridge University Press, 2004.

Home/Front. The Military, War and Gender in Twentieth-Century Germany, ed. Karen Hagemann, Stefanie Schüler-Springorum, Oxford and New York: Berg, 2000.

Iwasiów Inga, Centralna płeć cywila, w: Wojna - doświadczenie i zapis: nowe źródła, problemy, metody badawcze, red. S. Buryła, P. Rodak, Kraków: Universitas, 2006, s. $399-417$.

Kusiak-Brownstein Alicja, Płeć kulturowa, „doświadczenie” i wojna - kilka metodologicznych uwag o wykorzystaniu relacji wspomnieniowych, w: Kobieta i rewolucja obyczajowa. Społeczno-kulturowe aspekty seksualności. Wiek XIX $i$ XX, red. A. Żarnowska, A. Szwarc, Warszawa: Wydawnictwo DiG, 2005, s. 409-420.

Sierakowska Katarzyna, Śmierć, wygnanie, głód w dokumentach osobistych. Ziemie polskie w latach Wielkiej Wojny 1914-1918, Warszawa: Instytut Historii PAN, 2015.

Tec Nechama, Resilience and Courage. Men. Women and the Holocaust, New Haven CT: Yale University Press, 2003.

Ubertowska Aleksandra, Archeologie pamięci. Współczesne kobiece narracje o wojnie, w: Wojna i postpamięć, red. Z. Majchrowski, W. Owczarski, Gdańsk: Wydawnictwo Uniwersytetu Gdańskiego, 2011, s. 187-198.

Watson Alexander, Enduring the Great War. Combat, Morale and Collapse in the German and British Armies, 1914-1918, New York: Cambridge University Press, 2008.

Watson Alexander, Ring of Steel. Germany and Austria-Hungary in World War I, New York: Basic Books, 2014.

Watson Janet S.K., Fighting Different Wars. Experience, Memory, and the First World War in Britain, Cambridge: Cambridge University Press, 2004.

Women and Men at War. A Gender perspective on World War II and its Aftermath in Central and Eastern Europe, ed. M. Röger, Osnabrück: Ruth Leiserowitz, fibre Verlag, 2012.

Women and the Holocaust, eds. D. Ofer, L. Weitzmann, New Haven CT: Yale University Press, 1988.

\section{Kieszonkowy atlas kobiet, Dzidzia, Cwaniary: Sylwia Chutnik's Representations of War and Gender \\ Summary}

The article describes the motif of women and war in three novels by Sylwia Chutnik (born 1979): Kieszonkowy atlas kobiet (Pocket Atlas of Women) 2008, Dzidzia (Diddums) 2009 and Cwaniary (The Hustlers) 2012. 
Drawing from the context of modern Western studies, reflections on these works concern the relationship between gender and war, assuming that it grants an active and heroic role to men while putting women in the role of civilian victims, and in doing so, it consolidates the traditional social hierarchy. Even though the history of war contradicts such stereotypes and abounds in evidence of women's courage, both as civilians and soldiers, the society - according to scholars - seems to reproduce wartime division of gender roles as justification for the cultural hierarchy of gender. This pushes women's experience and memory of war to the margins of collective memory. Sylwia Chutnik portraits the women who participated in the Warsaw Uprising and depicts their lives after the war, rediscovering the (in)ability to build a women's tradition of combat and to pass their wartime stories to daughters and granddaughters. She also shows the forgotten women's memory of the Uprising: the terrible suffering of civilians, who often rebelled against military decisions. In her understanding, this memory forms an undertone in Polish culture, and has only recently been acknowledged by the so-called oral history.

Keywords: war, gender, Warsaw Uprising, Polish literature, Sylwia Chutnik 